\title{
SUPPORTING INTERNATIONAL FACULTY
}

\author{
PERSPECTIVES OF A TIGER TEACHER WHO ADAPTED
}

TO THE AMERICAN CLASSROOM, A COLLEAGUE, AND AN ADMINISTRATOR

Cuiting Li, Sterling K. Wall, Marty Loy, Kelly Schoonaert University of Wisconsin-Stevens Point

This chapter is an account of a Chinese faculty member's experiences integrating into American higher education. Told from three points of view, her story emphasizes the importance of openness and willingness to talk about cultural issues.

International scholars contribute to campus diversity, awareness of global contexts, scientific improvement, and international expertise (see Altbach, 2005, 2006; Horn, Hendel, \& Fry, 2007; Mamiseishvili, 2010; NAFSA, 2006; Stromquist, 2007). The number of international students and scholars is increasing rapidly in colleges and universities. The Institute of International Education reported 126,123 international scholars teaching or doing research in U.S. universities during the 2007-2008 academic year, 8 percent more than the prior year (Institute of International Education, 2008). The 2004 National Study of Postsecondary Faculty 
(NSOPF: 04) survey found that 36.8 percent of foreign-born scholars in the United States were women.

However, it is not enough to recruit diverse faculty; ongoing communication and support must take place (Tuitt, Sagaria, \& Turner, 2007). International scholars have been found to be more involved in research and have more publications but are less engaged in teaching and less satisfied with their jobs compared to American faculty (Corley \& Sabharwal, 2007; Johnson \& Regets, 1998; Levin \& Stephen 1999; Mamiseishvili, 2010; Marvasti, 2005; Wells, 2007). Students continuously doubt and challenge the teaching quality of international faculty, which affects their teaching evaluation and promotion evaluation (Skachkova, 2007). Often international scholars excel in research functions but struggle in meeting teaching obligations (Mamiseishvili, 2010). Foreign-born teachers face many challenges, including language; accent; rejection by students; isolation; alienation; difficulty balancing teaching, scholarship, and service; lack of support; racism, prejudice; and bias (Essien, 2003; JacksonWeaver, 2011; Mamiseishvili, 2010; Mayuzumi, 2008; Michaels, 2011; Skachkova, 2000). Different cultural backgrounds and unfamiliarity with U.S. cultural norms in teaching and learning play a key role in these challenges (Thomas \& Johnson, 2004). Suggestions have been made to universities to help international faculty succeed in the teaching environment by, for example, pairing them with mentors, increasing institutional support, or trying to construct a friendlier environment (Fouad \& Carter, 1992; Atkinson, Brown, Casas, \& Zane, 1996; Moradi, \& Neimeyer, 2005; Pololi, 2010; Sharon, 2011). It important for administrators to realize that developing strategies for diverse faculty requires understanding cultural identity at the individual level (Smith, 2009).

Toward that end, this chapter is a case study of discovery, perseverance, and uncovering subtle nuances that vastly changed the experiences of both student and teacher. This is a story of an articulate, passionate, competent professor of Chinese descent, Cuiting $\mathrm{Li}$, and her experiences assimilating into a midsize university in upstate New York and then again at another university in the Midwest. The insights offered illustrate what is truly meant by "accepting cultural diversity."

This story is told from three perspectives: that of the foreign-born professor, Cuiting Li; her colleague, mentor, and friend, Sterling Wall; and her department chair, and now dean, Marty Loy. The story begins in China where $\mathrm{Li}$ was educated in the traditional Chinese way from elementary school, through middle and high school and then in the university. Like the recent media attention around Chinese "tiger mothers," one might say that in China, "tiger teachers" push students to the pinnacle of 
performance and are respected and loved because of their strict teaching methods (Chua, 2011).

\section{Li's Perspective}

\section{Tiger Teachers}

In China, I was taught by "tiger teachers" and thought they were very good teachers. Teachers had authority in everything, and students were not encouraged to question or disagree. If students did not do well on exams, teachers could yell at students and also at their parents. From elementary school, we were required to sit in class quietly-no moving, no talking, just listening and following teachers' directions. If someone couldn't concentrate on the teacher's lectures, the teacher would throw chalk at the student, often hitting the student's face. Sometimes the teacher would quietly go over to that unattentive student and pull him or her out of the seat suddenly. The student would be shocked and stand there red-faced as classmates stared, like a thief caught red-handed. Sometimes the teacher might call the student's name and ask him or her to answer a question. The student would stand there speechless, in front of classmates and the teacher because not being able to answer the teacher's questions was shameful.

I was not a good student in the early years (I was always distracted by pens, pencils, flies, trees, sunlight, or my own thoughts) so I experienced this treatment from several times a day in elementary school to a few times each semester in middle and high school. Nevertheless, I grew up happily, had great memories about my school years, and never complained about the teachers or hated them. On the contrary, I loved school and I loved the teachers because I went to one of the best universities with their help (I was in the top 1 percent of students in the area). I firmly believed that good teachers should hold high expectations for students and that this type of behavior was necessary and accepted as evidence of high functioning, even for professors.

\section{Becoming a Professor}

Li finished her formal education in China and taught three years in a traditional Chinese university before coming to the United States to get a master's degree and Ph.D. in human development and family studies from Auburn University. Li's first job teaching as an assistant professor in a state school in New York was another kind of acclimation beyond her experiences as a student in America. This acclimation to American culture 
and the expectations of an American educator now took her to the next level of challenge and became much more difficult.

\section{Li's Perspective}

LANGUAGE CHALLENGES. When I started teaching, I worked very hard to be a good professor. I spent over ten hours preparing for each one-hour class. I was very serious about the material, lectured for the entire class period, and sometimes kept students longer than the allotted time because I thought (according to my background) that was how you prove you are diligent and competent - a master of content. Nevertheless, my student evaluations were bad. Students complained the class was boring, unclear, stressful, and even threatening. Feeling insulted, hurt, frustrated, scared, and confused, I worked even harder-and got worse evaluations.

Finally I began to identify and address some of my challenges. The first basic challenge I faced was speaking fluent English. I started learning British English at age twelve in China. After I came to the United States, I spent a lot of effort mastering English by reading scholarly articles. When I started teaching, I had no problem communicating material in my professional field of expertise. However, I did not understand my students when they talked about their lives outside the classroom. Academic topics were easy to talk about; real life was not. As I became friends with colleagues, I felt more at ease asking questions so that I could understand my students' examples and lives. I have tried using humor, but that doesn't always work. Sometimes my students or colleagues didn't think I was funny because Chinese humor doesn't translate well. So in class I use funny pictures instead of jokes for entertainment.

Sometimes I still have difficulty with language. Once I came to school at about 11:00 A.M. to get ready to teach that afternoon. One of my colleagues asked me if I had slept late. I smiled proudly and said, "Yes!" I was puzzled by the look she gave me. It was not until a year and a half later that I learned from another colleague that in America, "sleeping late" means getting up late. In China, "sleeping late" means you went to sleep late. In fact, when I was asked that question, I had stayed up until 4:00 A.M. preparing for class. Colloquialisms can be challenging.

One of my colleagues has suggested to me that I should tell my students to ask for clarification if they do not understand something that I have said in class. Taking a moment early in the semester to state the obvious-that there might be some confusion due to language differences-and then to instruct students on what to do if they do not understand a word or idea allows students to ask in a way that does not make the student or me uncomfortable. 
WORKLOAD AND TEACHING CHALLENGES. Sometimes I spend up to ten hours preparing for each lecture. In addition to understanding the material and planning how to teach it, I need to rehearse each sentence I want to say and learn the pronunciation of the words, especially if there is a specialized vocabulary. I used to write every sentence down and memorize them.

When I started teaching, I slept only five or six hours a night, even on the weekends, and had no leisure time. Few people understood why I was so busy and tired, including my best friends and my parents. I resented my teaching job for a long time. I no longer need as much preparation time, but it is still difficult to talk to anyone before class as I am making last-minute adjustments to my presentation.

I was surprised by some of the ways my colleagues conducted their classes, so different from my Chinese teachers. But over the years, I have changed my teaching, and I now use information from different sources besides the textbook-for example, news releases, videos, Web sites, magazines, and guest speakers. I also added online quizzes and surveys and the use of interactive activities where students can anonymously and electronically answer questions in class.

OUTSIDER STATUS. My students often still see me as an outsider. My colleagues shared with me the PowerPoints they were using in a different section of the same class I was teaching, and I used them, though with a few changes. But my students were angry about the grammatical mistakes I had made in my slides; they pointed out the mistakes immediately and criticized my English. But these errors were in the slides when I got them, and I was surprised that neither my colleagues nor their students had noticed these errors. In addition, students have complained that the wording in my exams was weird, or poor, yet these questions were taken from a publisher's test bank and had been selected by the American instructor who had preceded me. The students continued to complain even after I told them about this test bank. I remain extra conscious of my grammar when e-mailing students and colleagues.

\section{A New Position: Starting Over}

On the advice of graduate school friend and mentor, Sterling Wall, $\mathrm{Li}$ applied for a new position in Wisconsin that focused on increasing student exposure to diversity. $\mathrm{Li}$ accepted the offer, but that was just the start of the process of beginning a new job for both $\mathrm{Li}$ and her new employer.

The wait for a visa to get approval to transfer to a different university was about a year and a half. At that point, $\mathrm{Li}$ was already halfway through the green card application process (incurring expenses of about six 
thousand dollars, with each additional call to her lawyer paid from her own pocket) when she was offered the position, and she had already waited years for her application to be accepted. Li needed a green card to stay and work legally long term in the United States because a working visa allows only a six-year maximum in-country stay. If she could not get a green card within this period, she would have had to leave the country, permanently even if she had a job, because the working visa is directly connected to the job. If she changed jobs, she needed to restart the green card application process, which, for a Chinese citizen, is usually more than a five-year process. Therefore, changing jobs may have meant that she would not be able to get the green card within the required time frame.

Many delays kept the new position in limbo, and Li was very nervous about the effect that moving would have on her application. She worried, in fact, that she might have to start the green card process all over again. During that wait, she did not visit her family in China because she worried that she might not be allowed to reenter the United States with just the visa. She might also have lost the job and the right to work and stay in the United States if she did not obtain the visa in time.

During this time Li was in immigration limbo, she was unsure whether the job offer from Wisconsin would be rescinded or whether her New York employer would continue to employ her until her immigration status was clear. If that happened, she would have to return to China. But her department in Wisconsin covered her courses while she was waiting for all the paperwork to get sorted out, and finally things fell in place. She moved to Wisconsin, and the acclimation and adjustment process started all over again.

\section{Li's Perspective on Academic Adjustment}

I had gotten used to work in New York and made progress in teaching, and then I changed jobs. When I started teaching in Wisconsin, it was very frustrating: new courses, new students, new schedules, and even a new culture. I was back working day and night just to keep my head above water. My teaching evaluations and self-esteem were low, my frustration high, and I was depressed and lonely. It was very, very difficult.

My new university has a program called Teaching Partners, where faculty are paired with a mentor for a year to help them in their teaching. The mentor also meets periodically with the mentee's students, without the mentee there, to get their feedback about how the class is going. The mentor shares the results. I have finished the program, but I asked my mentor to come to my class several times last semester. His visits 
completely changed students' opinions of me! Each time he came to class, he told them that I was working hard to improve my teaching and that he was there to get their ideas on what I could improve. Through meeting with him and other colleagues, I made further progress addressing challenges to my teaching.

For example, I now go to class early to give students access to ask questions or chat. I used to believe good professors should not go to class early. In China, this never indicated a professor was proficient. There, if the professor was early, he or she waited outside the door until the appointed time, then entered and promptly began lecturing. It was an amazingly enlightening moment when, during a meeting with my department and personnel chairs, this cultural difference was brought to light.

I began trying some new class activities. I used to give students a list of questions to answer for each lecture so that they had to think instead of taking notes passively. I tried to engage students by calling on them individually by name to answer a question or give an example. I was frustrated that students never answered or raised their hands. Again, in another routine meeting, my department chair pointed out another cultural difference: our students are highly self-conscious and do not like to stand out. Dr. Wall, my mentor, suggested I use the think-pair-share method, where students first think about a question or concept and write briefly about it, then share answers with a partner. When I then asked questions, students were ready, willing, and able to share their answers since they had already discussed the topic with their classmates.

I began briefly introducing the content before I lectured. When I was growing up in China, I was taught to follow the teacher passively in class and was used to surprises, not knowing ahead of time what they might discuss. Again, thanks to my department chair, I learned that American students prefer to know the big picture first.

I tried to explain assignments in more detail. It turns out that my understanding of clarity is very different from that of my students. Many students like to envision the final product and feel uncomfortable if they are given too much latitude. Preparing students to accept more responsibility for envisioning a final product helps them accept that responsibility, and allowing them to participate in the development helps alleviate issues down the road.

I tried to be more encouraging and positive to students. I used to believe it was normal and good to be harsh and direct with students. Just as a Chinese person may say to a friend or family member, "You are fat; lose some weight," a Chinese teacher may tell a student, "You are wrong; do it again." Chinese professors are direct and to the point. They do not 
spend time worrying about students' reactions because harsh words mean teachers are just being honest, not offensive. Nevertheless, now that I frame feedback positively, the reactions from students are better.

These changes have helped me connect with students and improved my course evaluations. However, it does not mean that I have changed completely. I have become a bit more lenient with students, but I still find that I have had to rein in the amount of freedom students expect. My students had told me that during lectures, it was normal for students to talk, leave the room to go to the bathroom, text, or check e-mails. But I found that teaching a large-enrollment class became a huge challenge because students were distracted by their own and others' activities. Taking the advice of a colleague, I moved back to being stricter with classroom discipline once again. Now I have simple rules: no laptop, no cell phone ringing, and no talking-but I still smile. So returning to being the "Chinese tiger teacher" has made my teaching a big class more effective. Finding the median between both approaches, the Chinese and the American, is serving me well.

\section{A Colleague's Perspective: Sterling Wall}

\section{Communicating Openly Helps Cross Culture Barriers}

Sometimes when $\mathrm{Li}$ is co-teaching or working on a project with another faculty member who is higher ranking, older, or more senior, she often defers to that person, not offering many opinions and respecting the other's direction. To those of us in her department, it seemed baffling, and we wondered why she did not speak up. But we didn't say anything, so as not to be rude, and simply thought that she was not contributing. Later, however, Li confessed that she felt shut out because her colleagues did not acknowledge or bring up awkward issues. Once we all talked, however, we quickly were able to understand one another.

Especially noteworthy is that every time that Li has finally understood some of the underlying cultural differences, she immediately made changes. It was not for lack of desire and certainly not laziness. It is simply the very real difference between how she sees the world and how we do. Experiences we take for granted, she never had.

\section{Promoting Her Positive Image to Students Helps Both}

Last fall, before I began a guest lecture in Li's class, I told the students that they needed to know something about their instructor. I explained 
to them how hard she had worked at Auburn, day and night. I told them the funny story about how my wife and I taught her how to drive (we made her sit in the driver's seat and drive down the freeway with clenched fists around the wheel). I also told them about an e-mail that she had received last year when we had sent a mass announcement inviting them to study abroad for three weeks with her in China. A student had responded to her saying things like, "Aren't they the reason there is an overpopulation problem? Isn't that where SARS started? Aren't they taking all our jobs? Wouldn't it be better if they didn't exist? No, I don't want to go to China with you." Of course, Li was polite, as always, and had simply forwarded the e-mail to me asking, "Sterling, how should I respond to this?" My point to the class was that they have a hard-working person here, with a wealth of experience from a major country in the world, who is giving her very best efforts on their behalf. I then gave my lecture.

A couple of weeks later, $\mathrm{Li}$ showed me an e-mail from a different student, expressing gratitude for her hard work and lectures. Li was enormously pleased and happy. In fact, she told me that after my lecture, she could tell the difference in student attitudes toward her in that large class of three hundred. They were kinder, more respectful, and engaged.

\section{An Administrator's Perspective: Marty Loy}

One of a department chair's responsibility is to recruit, hire, and mentor new faculty who will help the department meet its mission. One of the goals of our department is to increase student exposure to all types of diversity. With $\mathrm{Li}$, we had an opportunity to bring a Chinese citizen faceto-face with our students, and because she was interested in leading study-abroad programs and creating a student exchange with China, many of our students could be exposed to one of the most interesting cultures in the world.

\section{Being Patient and Accepting Is Very Important}

Another responsibility of a department chair is to provide the support necessary to help faculty lead successful, rewarding academic lives, which includes getting them over the often pressure-filled hurdle of tenure. This is what led me to work closely with $\mathrm{Li}$ in her new role within our university.

Cuiting $\mathrm{Li}$ is a ball of complexity - a mix of strength, confidence, and independence with naiveté, seemingly illogical behaviors to my 
American sensitivities, and lack of "American common sense." I found her to be meek and charming, yet she was the toughest salary negotiator that I had ever encountered. She was a good thinker and accomplished scholar, yet she had difficulty understanding the financial aspect of buying a new house in America. She was so independent that she had left the security of her family in China, yet navigating the visa process confounded her. These dichotomies, as confusing as they were at the time, were, in hindsight, the result of simple differences of cultures. Being patient and accepting was very important when working with her because it was difficult to predict when language and culture barriers would arise.

\section{Understanding Culture}

Cultural differences created difficulties in her teaching too. It was hard work for me to understand Li's complexities, and her teaching evaluations were below average. She asked many questions, and because cultural differences would not allow her to fully accept the offered answers, sometimes she would ask the same question over and over again. Mentoring her took more of my time and energy than any other new faculty member had ever taken.

Our students, most of them from small town rural America, liked $\mathrm{Li}$ but struggled to understand her teaching. They said that she "made you feel horrible and embarrassed" or "appears rude and intimidating." By being direct with her feedback, $\mathrm{Li}$ was only trying to help, but they saw her comments as hurtful. By lecturing didactically, she was providing her students with an expert, which was surely something that they would appreciate, but they were more interested in each other's opinions than they were in hers. By coming to class a few minutes late, Li thought she was ensuring that her students had time to ready themselves for class. Instead, they felt that she was unapproachable and took the tardiness as a sign of being unorganized.

At first, it seemed to Li that the harder she worked, the worse her teaching evaluations became. I gave her Brookfield and Preskill's Discussion as a Way of Teaching: Tools and Techniques for Democratic Classrooms (2005), which I thought was a brilliant book, but it only confused her. I told her to smile more and be more personable to her students, but in light of her strict cultural behaviors, these suggestions confused her. I suggested that she just be herself when she taught, which of course caused her to accentuate all of those cultural differences that were already causing her trouble. 


\section{Enhancing Teaching}

Over time, and with a great deal of hard work on her part and on the parts of her colleagues and students, teaching became easier for Li. She gained insights into how cultural differences between students and teachers affect student satisfaction and learning and began to understand her students better. Li had more and more "aha" moments when she became more confident and comfortable, and a better teacher.

It has also been hard work for her students. But I am certain that now they leave her classrooms not only understanding required content but with a much better understanding of the complexities of the world. Over time and with hard work, I too began to appreciate $\mathrm{Li}$ and her culture. She and I have become close friends through all of this, and that is exactly the type of ending that 1 hope all of our students have when they encounter her.

\section{Summary of Success: Lessons Learned for Administrators and Colleagues}

The experience of learning to teach in the United State is interesting in many people's eyes because there are so many moments of epiphany. However, it has been a painful experience for Cuiting Li. Similar to other scholars from foreign countries, she experienced many difficulties: different teaching style expectations, misinterpretation of the language, a heavy workload, alienation, and criticism caused by mistrust (Essien, 2003; Jackson-Weaver, 2011; Mamiseishvili, 2010; Mayuzumi, 2008; Michaels, 2011; Skachkova, 2000).

Support and caring from colleagues and administrators was a key to her success. She would not have succeeded had she been left struggling by herself. At the individual level, understanding the concerns and experiences of international faculty, providing mentorship involving coaching, political management, and emotional support, are very important (Atkinson et al., 1996; Jackson-Weaver, 2011). In Li's case, unconditional acceptance and the following support from colleagues and administrators played a significant role in her successful transition and adaptation to teaching in a U.S. university:

- Being open and accepting even when asking questions that her students found awkward such as why they go home on the weekend or why they missed class for a doctor's appointment

D Observing her behavior and style and giving suggestions to remove blind spots due to culture differences 
o Addressing misunderstandings, frustration, or confusion openly

o Being patient, even when she asked the same questions over and over or when she did not immediately make alterations as suggested

o Creating a positive image of her in students' eyes, as colleagues stepped in to give her students a peek behind the scenes, helping them understand their foreign professor-her intentions, background, and that she had their best interests at heart

o Advocating for her when she was treated unfairly, even if she may not have even realized it

o Assisting her through ongoing discussion to clarify and frame her questions in a way that is understandable to all

o If possible, adapting her workload to compensate for these additional challenges

Li's experience is congruent with that of other studies and efforts supporting minority scholars. Many institutions are committed to achieving greater diversity. The Board of Ethnic Minority Affairs was founded in 1980, and the Commission on Ethnic Minority Recruitment, Retention, and Training was established in 1994 (American Psychological Association, 2003) to promote faculty diversity. At the institutional level, creating a supportive, inclusive, and collaborative environment; offering needed resources; providing fair treatment; holding realistic and balanced expectations; allotting reasonable teaching loads; and giving recognition are critical in recruiting and retaining minority faculties (Fouad \& Carter, 1992; Helms, 2001; Moradi \& Neimeyer, 2005; Olmedo, 1990; Pololi, 2010; Ridley, 1991; Sue, 2001). “Just having a safe person to ask cultural questions without fear of offending them would be extremely useful" to nonnative faculty members (Fredericks, 2011, p. 2).

\section{REFERENCES}

Altbach, P. G. (2005). Globalization and the university: Myths and realities in an unequal world. In National Education Association, The NEA 200.5 Almanac of Higher Education (pp. 63-74). Washington, DC: Author.

Altbach, P. G. (2006). The internationalization of higher education: Motivations and realities. In National Education Association, The NEA 2006 Almanac of Higher Education (pp. 27-36). Washington, DC: Author.

American Psychological Association. (2003). Guidelines on multicultural education, training, research, practice, and organizational change for psychologists. American Psychologist, 58, 377-402. 
Atkinson, D. R., Brown, M. T., Casas, J. M., \& Zane, N.W.S. (1996). Achieving ethnic parity in counseling psychology. Counseling Psychologist, 24, 230-258.

Brookfield, S. D., \& Preskill, S. (2005). Discussion as a way of teaching: Tools and techniques for democratic classrooms (2nd ed.). San Francisco, CA: Jossey-Bass.

Chua, A. (2011). Battle hymn of the tiger mother. New York, NY: Penguin. Corley, E., \& Sabharwal, M. (2007). Foreign-born academic scientists and engineers: producing more and getting less than their U.S.-born peers? Research in Higher Education, 48(8), 909-940.

Essien, V. (2003). Visible and invisible barriers to the incorporation of faculty of color in predominately white law schools. Journal of Black Studies, 34, 63-71.

Fouad, N. A., \& Carter, R. T. (1992). Gender and racial issues for new counseling psychologists in academia. Counseling Psychologist, 20, 123-140.

Fredericks, S. (2011). Supporting non-native faculty members. Tribal College Journal, 22, 37-38.

Helms, R. (2001). NBPTS: The highest form of certification. Kappa Delta Pi Record, 38(1), 20-23.

Horn, A. S., Hendel, D. D., \& Fry, G. W. (2007). Ranking the international dimension of top research universities in the United States. Journal of Studies in International Education, 11(3/4), 330-358.

Institute of International Education. (2008). Open doors 2008: International scholars. Retrieved from http://opendoors.iienetwork.org/?p=131567

Jackson-Weaver, K., (2011). Diversity and the future of the professoriate: A call to action. Diverse: Issues in Higher Education, 27, 27-27.

Johnson, J., \& Regets, M. (1998, June 22). International mobility of scientists and engineers to the United States-Brain drain or brain circulation? Washington, DC: National Science Foundation.

Levin, S. G., \& Stephen, P. E. (1999). Are the foreign born a source of strength for U.S. science? Science, 28.5(5431), 1213.

Mamiseishvili, K. (2010). Foreign-born women faculty work roles and productivity at research universities in the United States. Higher Education, 60, 139-156.

Marvasti, A. (2005). U.S. academic institutions and perceived effectiveness of foreign-born faculty. Journal of Economic Issucs, 39(1), 151-176.

Mayuzumi, K. (2008). "In-between" Asia and the West: Asian women faculty in the transnational context. Race, Ethnicity and Education, 11(2), 167-182.

Michaels, W. B. (2011, Winter). The trouble with diversifying the faculty. Liberal Education, 14-19. 
Moradi, B., \& Neimeyer, G. J. (2005). Diversity in the ivory white tower: A longitudinal look at faculty race/ethnicity in counseling psychology academic training programs. Counseling Psychologist, 33, 655-675.

NAFSA: The Association of International Educators. (2006). Restoring U.S. competitiveness for international students and scholars. Retrieved from http://www.nafsa.org/uploadedFiles/NAFSA_Home/Resource_Library_ Assets/Public_Policy/restoring_u.s.pdf? $n=8823$

Olmedo, E. L. (1990). Minority faculty development: Issues in retention and promotion. In G. Stricker, E. Davis-Russell, E. Bourg, E. Duran, W. R. Hammond, J. McHolland, .. . Vaughan, B. E. (Eds.), Toward ethnic diversification in psychology education and training (pp. 99-104). Washington, DC: American Psychological Association.

Pololi, L. (2010, September 4). A prescription for diversifying medical-school faculties. Chronicle of Higher Education, 57, 32-34.

Ridley, S. E. (1991). Faculty development and retraining: Some committee recommendations. In H. F. Myers, P. Wohlford, L. P. Guzman, \& R. J. Echemendia (Eds.), Ethnic minority perspectives on clinical training and services in psychology (pp. 165-168). Washington, DC: American Psychological Association.

Skachkova, P. (2007). Academic careers of immigrant women professors in the U.S. Higher Education, 5.3, 697-738.

Smith, D. G. (2009). Diversity's promise for higher education: Making it work. Baltimore, MD: Johns Hopkins University Press.

Stromquist, N. P. (2007). Internationalization as a response to globalization: Radical shifts in university environments. Higher Education, .53, 81-105.

Sue, D. W. (2001). Surviving monoculturalism and racism: A personal and professional journey. In J. G. Ponterotto, J. M. Casas, L. A. Suzuki, \& C. M. Alexander (Eds.), Handbook of multicultural counseling (2nd ed., pp. 45-54). Thousand Oaks, CA: Sage.

Thomas, J. M., \& Johnson, B. J. (2004). Perspectives of international faculty members: Their experiences and stories. Education and Society, 22(3), 47-64.

Tuitt, F. A., Sagaria, M. A., \& Turner C. S. (2007). Signals and strategies in hiring faculty of color. Higher Education: Handbook of Theory and Research, 22, 497-535.

Wells, R. (2007). International faculty in U.S. community colleges. In E. Valeau \& R. L. Raby (Eds.), New directions for community colleges, No. 1.38: International reform efforts and challenges in community colleges (pp. 77-82). San Francisco, CA: Jossey-Bass. 